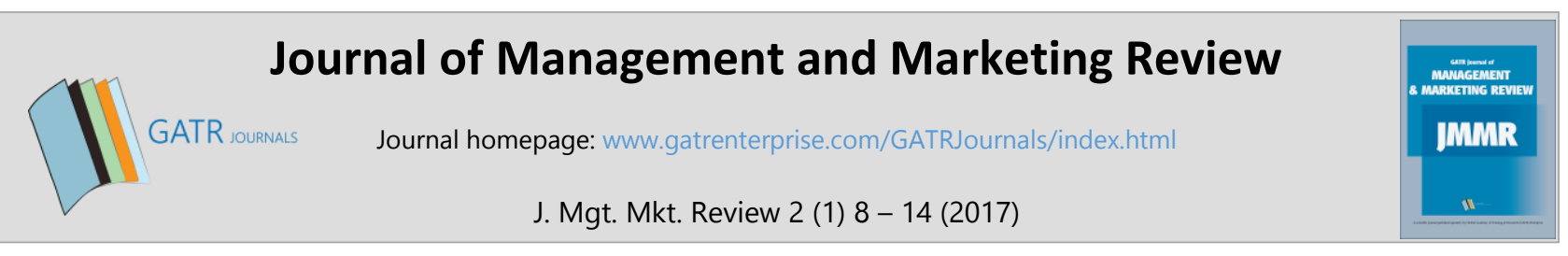

\title{
Greenwashing and Its Impact on Consumer Confidence - Case Study of Slovak Republic
}

\author{
Jana Kliestikova ${ }^{1 *}$ and Margareta Nadanyiova ${ }^{2}$ \\ ${ }^{1,2}$ Faculty of Operation and Economics of Transport and Communications, University of Zilina, Univerzitna 1, 01026 Zilina, Slovak \\ Republic
}

\begin{abstract}
Objective - This paper is focused on the topic of greenwashing and its impact on consumer confidence in specific conditions of Slovak republic. Nowadays, consumer confidence is mainly recognized as economic indicator measuring the interpretation of the current economic environment by consumers and their expectations for the future. In presented paper, we analyse greenwashing as a possible source of discontent. Greenwashing is a negative phenomenon of green marketing activities realised in the scope of corporate social responsibility.

Methodology/Technique - First, green characteristics of Slovak consumers are analysed in context of Hofstede cultural dimensions of Slovak republic. Subsequently, there is evaluated realised questionnaire survey dedicated to the analysis of greenwashing impact on consumer confidence. Then, the relationship between greenwashing and consumer confidence in Slovak market, is detected.

Findings - Results showed that attitude of authority has an impact on consumer confidence and the greenwashing has not got an impact on buying behavior of Slovak consumers.

Novelty - It has a vital importance to analyze socio-cultural profile of the nation and in accordance with obtained results highlight the importance of environmental education of the society.

Type of Paper: Review
\end{abstract}

Keywords: Green Marketing; Greenwashing; Corporate Social Responsibility; Consumer Confidence.

JEL Classification: D11, E21, M31.

\section{Introduction}

Currently, enterprises need to accept that communicating environmental and sustainability issues has more and more strategic importance for their effective market performance (Sukalova \& Ponisciakova 2013; Montecchia et al., 2016). Why is it so? Generally, it has been demonstrated that there is positively correlated relationship between CSR activities and loyalty of consumers resulting in market position (Bansal \& Roth, 2000; Mohr et al., 2001; Porter \& Kramer 2002). The same is valid also for green marketing as partial CSR conception (Banyte et al., 2010, Akenji 2014). Maniatis (2016) proved the influence of consumers' knowledge,

\footnotetext{
Paper Info: Received: January 7, 2017

Accepted: March 5, 2017

* Corresponding author:

E-mail: jana.kliestikova@fpedas.uniza.sk

Affiliation: Faculty of Operation and Economics of Transport and Communications, University of Zilina,

Slovak Republic
} 
commitment, and general awareness related to green products on their green consciousness while making decisions for buying green products.

Akehurst et al. (2012) analysed the profile of green consumer in scope of its socio-demographic and psychographic variables with intention to re-examine the determinants of ecologically intended consumer behaviour. Moreover, there have been defined determinants of the green purchasing behaviour effectiveness taking the into account factors as environmentally conscious buying behaviour and already indicated purchasing intention. The results showed that psychographic variables are more relevant than sociodemographic variables when we try to explain mechanisms of ecologically oriented buying behaviour. It has been also detected that consumers with more conscious environmentally oriented buying behaviour have also higher green intention to purchasing. There has been also detected the existence of positive impact of ecologically intended buying behaviour on green purchase behaviour. Level of this impact is higher than green purchase intention, which in turn mediates that relationship.

But regional approach with respect to national environmental specifics was really applied much more later (Bravo et al., 2012, Owusu \& Anifori 2013; Aschemann-Witzel \& Aagaard 2014; Du et al., 2016). In these terms, Du (2015) realised the analysis of Chinese stock market and he found out that greenwashing is significantly negatively correlated with cumulative abnormal returns around the exposure of greenwashing. At the same time, also the topic of consumers' skepticism toward green marketing activities was highlighted (Kim \& Lyon 2015, Ulusoy \& Barretta 2016). It is mainly because marketing managers frequently try to convert low-involvement products into high-involvement ones by adding them features which are perceived as valuable from the consumer point of view (Zvirgzdina et al., 2015). Also, everyday practice shows that it is sufficient to add environmental character to the ordinary product and the result is increase of consumer involvement in the buying decision (Thogersen et al., 2012, Haws et al., 2014).

According to Marquis et al. (2016), companies with environmentally damaging production are less willing to be engaged in selective disclosure. This is mainly valid in countries where these companies are more exposed to moral and legal control. But this is not a reason for do not exploit advantages resulting from consumer loyalty as a consequence of consumer confidence. On the contrary, less social responsible companies are committing more greenwashing (Mala \& Musova, 2015). It is because such companies have more tendencies to manipulate public opinion and consumer preferences by publishing intentionally modified information about themselves and their products (Hes \& Regnerova, 2013). Companies which behave socially responsible are less willing to communicate their green performance without real environmentally conform background (Goncalves et al., 2016). There are these possible combinations of approach to corporate social responsibility and commitment of greenwashing:

- company is socially responsible and is avoiding greenwashing,

- company is socially responsible and is committing greenwashing,

- company is not socially responsible and is committing greenwashing,

- company is not socially responsible and is avoiding greenwashing.

So, the goal of presented contribution is to provide analysis of the consumer sensitiveness on greenwashing and the impact of this negative phenomena on consumer confidence.

Ho et al. (2012) and Yang et al. (2014) emphasise the necessity of Hofstede cultural dimensions acceptance when marketing activities and their effectiveness and impact on consumer loyalty and confidence are analysed. Basic dimensions of Hofstede theoretical concept are:

- $\quad$ power distance - expresses how less powerful members of a society accept the inequality in power distribution,

- individualism - expresses society with weak social relationships where individuals take care only of themselves, while collectivism, expresses society with strong social relationships where it is expected that members of social group will take care of others, 
- masculinity - expresses social preferences for achievement, heroism, assertiveness and material rewards for success, while femininity, in opposite, expresses social preferences for cooperation, modesty, caring for the weak and quality of life,

- uncertainty avoidance - expresses if members of a society feel uncomfortable with social uncertainty and ambiguity and how is the level of such feelings,

- long term orientation - expresses the strength of relationship with own past of the society in the processes of current and future problems solving and challenges acceptance,

- indulgence - expresses low level of difficulties when satisfying basic and natural human needs in scope of such incentives as enjoying life and having fun while restraint expresses its opposite, i.e. the high of level of basic needs satisfaction suppression.

Figure 1 shows structure of Hofstede cultural dimensions of Slovak republic, which should be accepted when the possible impact of greenwashing on consumer confidence is discussed.

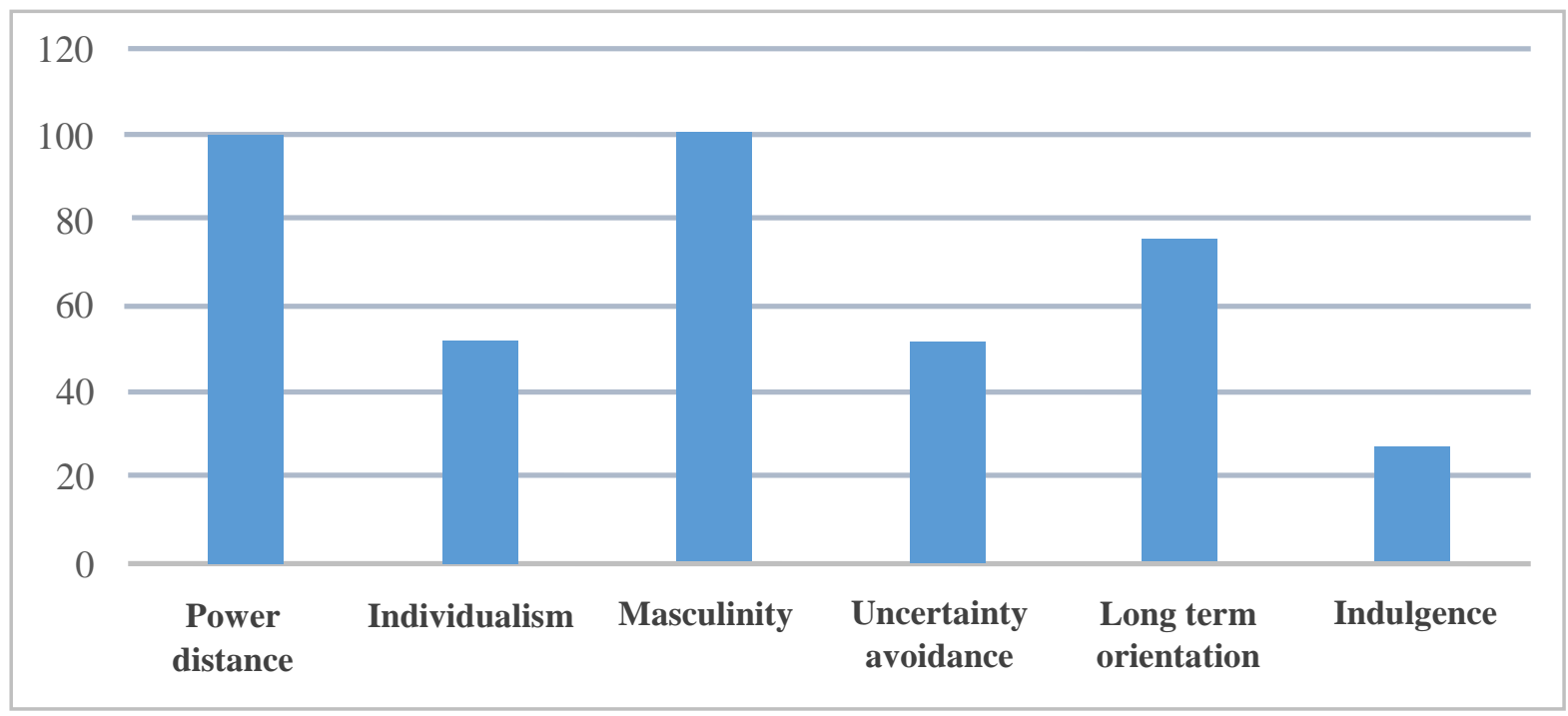

Figure 1. Hofstede cultural dimensions of Slovak republic

As it is shown in figure 1, Slovak republic reaches quite high level of indicators power distance (100\%), masculinity (100\%) and long term orientation (77\%). The interpretation of this state in terms of greenwashing impact on consumer confidence is the following:

- according to high score of power distance indicator, it is obvious that possession of more power of some people in comparison with others is fully accepted by society and that it is expected that this power will be used appropriately, i.e. we can suppose that there will be not greenwashing perceived until respected authority will detect it,

- according to high score of masculinity indicator, there will be an evident presence of phenomena like competition, achievement and success in the society (the most successful will be perceived as the best one, i.e. the selected first one in the small social group), i.e. we can suppose that there will be greenwashing perceived depending on image of company which is committing it,

- according to high score of long term orientation indicator, society of Slovak republic is characterized by its pragmatic culture (members of such societies believe that there is a strong possitive correlation between truth and variables as actual situation, context and time), i.e. we can suppose that there will be confidence of consumers less sensitive on greenwashing. 


\section{Methodology and data}

The identified research problem consists in insufficient knowledge about the impact of greenwashing on consumer confidence in specific conditions of Slovak republic. The survey was realized during the first quarter of year 2016. As Stofkova \& Stofkova (2010) recommend, we chose a semi-structured written questionnaire as a basic tool for the realization of this survey.

Our survey was addressed to 384 Slovakians older than 15 years. This age restriction results from the valid Slovak law where this age limit has been set for obtaining labour legal personality as a basic prerequisite for autonomous buying decision making (it is because purchase is not possible without having own disposable money to spend).

In accordance above mentioned theoretical approaches to the solved research problem and knowledge about Slovak consumer's specifics (Krizanova et al., 2016), we set following hypotheses:

- Hypothesis H1: The attitude of authority to greenwashing has an impact on consumer confidence.

- Hypothesis H2: The greenwashing has not got an impact on buying behavior of Slovak consumers.

\section{Results}

When hypotheses are formulated and subsequently tested by selected statistical methods, it is vital to define methodologically how we quantified the term "majority". We applied the approach of Krizanova et al. (2014), who argue that majority is reached when analyzed feature appear more than 50\% in responses of respondents. To test hypotheses which we previously set, we chose binomial test. This test is based on binomial distribution usage to verify the hypothesis consisting in two alternatives in which we have to analyze which one of them really occurs. (Janoskova \& Kral 2015).

\subsection{Verification of hypothesis $\mathrm{H} 1$}

We verified hypothesis $\mathrm{H} 1 \mathrm{using}$ the binominal test which serves to reject or accept the null hypothesis $\mathrm{H}_{0}$.

- Hypothesis $\mathrm{H}_{0}$ : The attitude of authority to greenwashing has not an impact on consumer confidence.

- Hypothesis $\mathrm{H}_{1}$ : The attitude of authority to greenwashing has an impact on consumer confidence.

In accordance with Gogolova and Ponisciakova (2013), we used these characteristics for the testing of hypothesis (1):

$t=\frac{|\bar{x}-\mu|}{\sigma} \Rightarrow \frac{x-n p}{\sqrt{n p q}}=\frac{\frac{x}{n}-\frac{n p}{n}}{\frac{\sqrt{n p q}}{n}}=\frac{\tilde{p}-p}{\sqrt{\frac{p q}{n}}}$

Where:

- $\mathrm{x}$ the frequency of the trait,

- $\mathrm{n}$ the frequency of observed phenomena,

$-\mathrm{p}$ predicted probability of the phenomenon incidence,

- $\mathrm{q}$ probability of alternative phenomenon frequency,

- p statistical probability of the phenomenon incidence. 
Substituting equation (1), we calculated the testing characteristic value $(8,453)$. To calculate the value of the critical testing characteristic we used the function NORMINV $(0,05 ; 0 ; 1)$ in the Microsoft Excel $(-1,523)$. To accept the null hypothesis $\left(\mathrm{H}_{0}\right)$, the value of testing characteristic has to be minor than value of the critical testing characteristic. But as the value of the critical testing characteristic is minor than the value of testing characteristic $(8,453>-1,523)$, the null hypothesis $\left(\mathrm{H}_{0}\right)$ is rejected. So, the alternative hypothesis $\left(\mathrm{H}_{1}\right)$ is accepted at the significance level 0,05 . According to this, it has been proved that the attitude of authority has an impact on consumer confidence.

\subsection{Verification of hypothesis $\mathrm{H} 2$}

To verify this hypothesis, it was also used the binominal test. So, the formulation of null hypothesis $\mathrm{H}_{0}$ is the base of hypothesis testing also in this case.

- Hypothesis $\mathrm{H}_{0}$ : The greenwashing has not got an impact on buying behavior of Slovak consumers.

- Hypothesis $\mathrm{H}_{1}$ : The greenwashing has an impact on buying behavior of Slovak consumers.

Substituting equation (1), we calculated the testing characteristic value $(-1,73)$. To calculate the value of the critical testing characteristic we used the function NORMINV $(0,05 ; 0 ; 1)$ in the Microsoft Excel $(-1,455)$. To accept the null hypothesis $\left(\mathrm{H}_{0}\right)$, the value of testing characteristic has to be more minor than the value of the critical testing characteristic. As the value of the critical testing characteristic is mayor than the value of testing characteristic $(-1,455<-1,73)$, the null hypothesis $\left(\mathrm{H}_{0}\right)$ is accepted. So, the alternative hypothesis $\left(\mathrm{H}_{1}\right)$ is rejected at the significance level 0,05 . According to this, it has been proved that the greenwashing has not got an impact on buying behavior of Slovak consumers.

\section{Conclusion}

The issue of greenwashing and its negative impact on consumer confidence has to be discussed not only in terms of managerial practice, but also marketing theory. The reason is that more and more companies try to exploit competitive potential which is contained in green marketing usage without real social responsible behavior on market. Greenwashing occurs mainly by communicating green activities while the real practice of the company is different. This could be a source of consumer confidence decrease which can cause loss of consumer loyalty and have so really damaging impact on existence of committing company. It seems to be a fair natural sanction for such incorrect behavior. But do really all consumers perceive greenwashing as a stimulus for loss of confidence? This tried to find response to this answer in specific conditions of Slovak republic and our findings are quite alarming. We found out that real impact on consumer confidence when greenwashing occurs has the attitude of relevant authority because in general, greenwashing has not got an impact on buying behavior of Slovak consumers. These findings are not good neither for the companies nor the society because if self regulating mechanism which eliminates such an incorrect company's market behavior does not exist, not only optimal market functioning but also sustainable development of society is endangered. So, it has a vital importance to analyze socio-cultural profile of the nation and in accordance with obtained results highlight the importance of environmental education of the society.

\section{Acknowledgements}

This paper is an output of scientific project VEGA no. 1/0024/15: The fundamental research of perception of corporate social responsibility as value for customer. 


\section{References}

Akehurst, G., Afonso, C. and Goncalves, H.M. (2012). Re-Examining Green Purchase Behaviour and the Green Consumer Profile: New Evidences. Management Decision, 50 (5), 972-988.

Akenji, L. (2014). Consumer Scapegoatism and Limits to Green Consumerism. Journal of Cleaner Production, 63, 1323.

Aschemann-Witzel, J. and Aagaard, E.M.N. (2014). Elaborating on the Attitude-Behaviour Gap Regarding Organic Products: Young Danish Consumers and In-Store Food Choice. International Journal of Consumer Studies, 38 (5), 550-558.

Bansal, P. and Roth, K. (2000). Why Companies Go Green: A Model of Ecological Responsiveness. Academy of Management Journal, 43 (4), 717-736.

Banyte, J., Brazioniene, L. and Gadeikiene, A. (2010). Začiatok formulára Expression of Green Marketing Developing the Conception of Corporate Social Responsibility. Inzinerine Ekonomika-Engineering Economics, 21 (5), 550560 .

Bravo, R., Matute, J. and Pina, J.M. (2012). Corporate Social Responsibility as a Vehicle to Reveal the Corporate Identity: A Study Focused on the Websites of Spanish Financial Entities. Journal of Business Ethics, 107 (2), 129-146.

Du, X.Q., Chang, Y.Y., Zeng, Q., Du, Y.J. and Pei, H.M. (2016). Corporate Environmental Responsibility (CER) Weakness, Media Coverage, and Corporate Philanthropy: Evidence from China. Asia Pacific Journal of Management, 33 (2), 551-581.

Du, X.Q. (2015). How the Market Values Greenwashing? Evidence from China. Journal of Business Ethics, 128 (3), 547574.

Gogolova, M. and Ponisciakova, O. (2013). Evaluation of the Quality Service Criterions of Public Transport. Proceedings of 17th International Conference on Transport Means (322-325). Kaunas Univ Technol, Kaunas, Lithuania.

Goncalves, H.M., Lourenco, T.F. and Silva, G.M. (2016). Green Buying Behavior and the Theory of Consumption Values: A Fuzzy-Set Approach. Journal of Business Research, 69 (4), 1484-1491.

Haws, K.L., Winterich, K.P. and Naylor, R.W. (2014). Seeing the World through GREEN-Tinted Glasses: Green Consumption Values and Responses to Environmentally Friendly Products. Journal of Consumer Psychology, 24 (3), 336-354.

Hes, A. and Regnerova, M. (2013). CSR and Availability of Food for Celiacs in Retail Trade CR. Proceedings of 22nd International Scientific Conference on Agrarian Perspectives - Development Trends in Agribusiness (349-360). Prague Czech Republic.

Ho, F.N., Wang, H.M.D. and Vitell, S.J. (2012). A Global Analysis of Corporate Social Performance: The Effects of Cultural and Geographic Environments. Journal of Business Ethics, 107 (4), 423-433.

Janoskova, K. and Kral, P. (2015). Optimal Timing of Innovation as a Precondition of Successful Innovation on the Global Market. Proceedings of 15th International Scientific Conference on Globalization and its Socio-Economic Consequences (254-259). Rajecke Teplice Slovakia.

Kim, E.H. and Lyon, T.P. (2015). Greenwash vs. Brownwash: Exaggeration and Undue Modesty in Corporate Sustainability Disclosure. Organization Science, 26 (3), 705-723.

Krizanova, A., Masarova, G., Buc, D. and Kolencik, J. (2014). Marketing Research as a Tool of Customers' Contentment Determination. Proceedings of 2nd International Conference On Economics And Social Science (92-97). Shenzhen Peoples R China.

Krizanova, A. Moravcikova, K. and Rypakova, M. (2016). The Social Area of Corporate Social Responsibility Focusing on Social Policy. Proceedings of 5th International Conference on Applied Social Science (339-344). Limassol Cyprus.

Mala, D. and Musova, Z. (2015). Perception of implementation processes of green logistics in SMEs in Slovakia. Proceedings of 4th World Conference on Business, Economics And Management (139-143). Ephesus Turkey.

Maniatis, P. (2016). Investigating Factors Influencing Consumer Decision-Making While Choosing Green Products. Journal of Cleaner Production, 132, 215-228.

Marquis, C., Toffel, M.W. and Zhou, Y.H. (2016). Scrutiny, Norms, and Selective Disclosure: A Global Study of Greenwashing. Organization Science, 27 (2), 483-504.

Mohr, L.A., Webb, D.J. and Harris, K.E. (2001). Do Consumers Expect Companies to Be Socially Responsible? The Impact of Corporate Social Responsibility on Buying Behavior. Journal of Consumer Affairs, 35 (1), 45-72. 
Montecchia, A., Giordano, F. and Grieco, C. (2016). Communicating CSR: Integrated Approach or Selfie? Evidence from the Milan Stock Exchange. Journal of Cleaner Production, 136 (SI), 42-52.

Owusu, V. and Anifori, M.O. (2013). Consumer Willingness to Pay a Premium for Organic Fruit and Vegetable in Ghana. International Food and Agribusiness Management Review, 16 (1), 67-86.

Porter, M.E. and Kramer, M.R. (2002). The Competitive Advantage of Corporate Philanthropy. Harvard Business Review, 80 (12), 56-+.

Stofkova, K. and Stofkova, J. (2010). Implementation of the Knowledge Management as a Competitive Advantage. Proceedings of Edulearn10: International Conference on Education And New Learning Technologies (13231328). Barcelona Spain.

Sukalova, V. and Ponisciakova, O. (2013). Management of a Transport Company in Terms of Critical Changes. Proceedings of 17th International Conference on Transport Means (70-74). Kaunas Univ Technol, Kaunas, Lithuania.

Thogersen, J., Jorgensen, A.K. and Sandager, S. (2012). Consumer Decision Making Regarding a "Green" Everyday Product. Psychology \& Marketing, 29 (4), 187-197.

Ulusoy, E. and Barretta, P.G. (2016). How Green Are You, Really? Consumers' Skepticism toward Brands with Gren Claims. Journal of Global Responsibility, 7 (1), 72-83.

Yang, L.M., Li, Y.T., Zhang, J.Y. and Wang, H.B. (2014). The Research of Online Shoppers' Behavior of CN-US Based on Hofstede Cultural Framework. Proceedings of International Conference on Information Technology and Management Engineering (320-325). Hong Kong Peoples R China.

Zvirgzdina, R., Linina, I. and Vevere, V. (2015). Efficient Consumer Response (ECR) Principles and Their Application in Retail Trade Enterprises in Latvia. European Integration Studies, 9, 257-264. 